\title{
T. S. Eliot's "La Figlia Che Piange" and the Tradition of Decadent Aestheticism
}

\begin{abstract}
In this essay, T. S. Eliot's "La Figlia Che Piange" - a modernist but also uniquely Romantic and Decadent lyric - is read in terms of its relationship with the tradition of British Decadent Aestheticism: viewed as both an invocation of Decadent sensibility and a critique of it. The Decadent strategies of Eliot's poem are explored with a focus shifting from grammar, to imagery, to the speaker's position, and to the interweaving of irony and emotion. These Decadent tactics are also discussed in the context of their parallels present in the works of Walter Pater, Oscar Wilde, Austin Dobson, Max Beerbohm, Aubrey Beardsley and Ernest Dowson. Notably, with Pater, Dobson and Dowson, a direct inspiration, rather than a parallel, is suggested - a literary influence on the poet who still puzzles contemporary critics with the fact, recorded in Sitwell's memoir, of occasionally sporting green face powder which, as the famous green carnation, was seen as emblematically Decadent.
\end{abstract}

Key words

T. S. Eliot; "La Figlia Che Piange"; Decadence; irony; emotion

In the years 1910-1911, T. S. Eliot was caught in a vortex of divergent influences. He graduated from Harvard, where he had studied under Josiah Royce, absorbing the lesson of philosophical idealism, and had become acquainted with the biological pragmatism of Royce's lifelong friend, William James. It was a difficult, twofold intellectual legacy for a poet preoccupied with the problem of expressing emotion. He had been also influenced by Irving Babbitt's new humanism and his idea of tradition, but he was not unaware of George Santayana's "feline aestheticism" (Freedman 1990: 122). In the realm of poetry, he remained fascinated by the work of Jules Laforgue. It was introduced to him for the first time, in 1908, 
through Arthur Symons's The Symbolist Movement in Literature, a lengthened version of Symons's concise (and, some claim, more successful) The Decadent Movement in Literature which, as Eliot confessed, "influenced the course of his life." Besides Laforgue, Eliot read works by John Davidson, Ernest Dowson, and an earlier poet, James Thomson, which he considered as the "only nourishment" in his early days (Ackroyd 1984: 34, 33). ${ }^{1}$ Fresh from Harvard, Eliot travelled to Europe and became immersed in the intellectual climate of Paris, and then, he spent the summer of 1911 journeying through Bavaria and northern Italy. His writing of "La Figlia Che Piange" was inspired by an image of a stele with a girl carved in it, which Eliot wished to see in northern Italy but failed to locate. In the museum records it was filed as "a young girl weeping," otherwise, remaining nameless. Accordingly, as critics explain, the epigraph to the poem, which Eliot derived from the Aeneid, refers to the scene in which Aeneas, not knowing how he should address the beautiful girl - the mythological Venus standing in front of him - asks her: "Maiden by what name shall I know you?"2

To Eliot, the poem held particular significance: he concluded with "La Figlia Che Piange" his first book of poetry, Prufrock and Other Observations (published in 1917). By placing "La Figlia" - rather than one of the shorter satirical pieces written in the years 1914-15 - at the end of the volume, Eliot ignored the sequence in which the poems of this volume were created. This essay seeks to show why this breach of chronology might be significant by viewing "La Figlia" as a lyric that, while standing on the brink of Modernism, was also a summation of the motifs and attitudes derived from Decadent Aestheticism.

Eliot's aesthetic allegiance to Decadent Aestheticism in "La Figlia" was tangentially suggested by Ronald Bush describing the speaker as "dandified" (1984: 12-13). It was also suggested by Grover Smith, who stresses Eliot's uncertainty about his aesthetic allegiance at the time he wrote "La Figlia." To Smith, the poem encompasses two traditions: on the one hand, a late romantic convention, in the "postures" taken from Tennyson and Rossetti, and on the other hand, the Symbolist tendency, apparent in the irony derived from Laforgue (1956: 28). However, the earlier approaches predominantly emphasise either the theme of love or an autobiographical element viewed in terms of a reminiscence or, alternately, an anticipation of a parting. ${ }^{3}$ It is in the later readings, as that by Derek Roper (2002), that the aesthetic perspective is underlined. Roper directs the Eliot reader to the art of painting and argues that, in composing the poem, Eliot employed a nineteenth-century poetic practice (actually, developed by the poets of the nineties) of the "picture poem" $(224 ; 233 n 7)$. Viewing the poetic image of the weeping girl as a painted picture (rather than a sculpted stele), possibly imaginary, he also shifts the critical attention from an event of the heart and the mind - a reminiscence and a projection - to an event of the eye: an act of perception. In his interpretation, "La Figlia" is read as recording a poet's "response to a work of figurative art" (233n7). Roper does not attempt to determine which particular picture underlays Eliot's poem. Instead, he emphasizes and proves the poem's link with a specific aesthetic convention. ${ }^{4}$ (His cautious attitude has its uncanny analogy in Decadent 
literature. Indeed, by discouraging the search for a specific picture, Roper prudently avoids the pitfalls of the type described, tongue-in-cheek, in Wilde's "The Portrait of Mr. W. H.," where attempts to furnish an actual picture in support of a literary theory prove impossible.) However, at the end of his critical essay, Roper draws our attention to the problem which lingers there for other readers to explore. Since "La Figlia" is "a picture without a frame," meaning that its relation to any specific painting in a museum or a picture gallery cannot be determined, its significance extends beyond the aesthetic. To Roper, then, the poem raises the ethical questions of art "giving first place to aesthetic values" (232) and of an artist's impassiveness.

The problems of "detachment" and of a suppressed passion were suggested by Bush and by Eric Sigg. To Bush, there is a pent-up emotion, curbed by irony (1984: 13); Sigg, in turn, explains that the speaker's apparent indifference to the girl's feeling is a result of him being confused about his own" (1989: 96). The problem of emotion is also emphasised by C. M. Shanahan (1955), who discusses Eliot's use of Laforguian irony as a safeguard against emotionalism, and by Denis Donoghue (2000), who claims that emotion is brought into the poem from the literary texts to which it alludes. In both cases, it would seem, Eliot "escapes" genuine emotion: he either presents it as empty - that is, hollowed by irony - or, by relying on the mythological motif, substitutes the raw feeling with what he would later call the "significant emotion" of art (1976: 22). The tradition of reading the poem as dealing with the matter of a suppressed emotion is continued by Martin Scofield, who reads it as a critique of the doctrine of impersonality which Eliot exposed in "Tradition and the Individual Talent." Actually, "La Figlia Che Piange" preceded "Tradition" by six years, but Scofield argues that it "is immaterial to the point" he makes (1988: 69). Indeed, the poem involves a spectrum of the Eliotean concerns with emotion and form as they would appear in his later poetry and criticism, thus encouraging, as in Scofield's analysis, a synchronic reading of Eliot's oeuvre, or a recognition of "the permanent in the changing." The present essay, however, rather than viewing "La Figlia" as an anticipation of what would be the ethical error of "Tradition and the Individual Talent," proposes to read the poem as Eliot's examination of what was to him the ethical error of Decadent Aestheticism. It looks at "La Figlia" as both invoking and undermining Decadent Aestheticist sensibility.

A similar strategy characterizes Eliot's "Portrait of a Lady." It is thematically connected with "La Figlia" in featuring a cruel aesthete and a woman associated with death, ${ }^{6}$ and it relies on similar tactics: the paradoxical procedure described by Richard Shusterman as that of art revealing high art's potential for the critique of its own strategies. In "Portrait," the eponymous Lady is about to be deserted by her younger male friend; yet, it is the young man, suddenly stricken by the thought of her death, whose self-confidence is, eventually, damaged. His thought of her dying, as Shusterman has it, initially exposes art's proclivity "to prey on human feeling rather than develop it." However, the danger that the poem would supply an aesthetic vision in place of empathy is also revealed by this very poem. 
The young man looks in the mirror - an archetypal symbol of art - and, in his own reflection, apprehends his insincerity and cruel detachment. Symbolically, then, "Portrait of a Lady," in Shusterman's words, brings to light "Eliot's paradoxical aestheticization of the ethical in attempting to criticize precisely that error" (1992: 164, 166-67). Analogously, "La Figlia Che Piange" reflects Decadent Aestheticist imagery and attitudes: the Decadent preoccupation with temporal flow, the theme of art as an antidote to death, the tropes of the cruel aesthete and the cognitive flâneur, and the imperative of emotional detachment. But these motifs are invoked only to be undermined - the poem resorts to such profound irony as was typical of Decadence, the tradition it both embraces and repudiates.

\section{1. "Perpetual flux"}

The linking of "La Figlia" and the "picture-poem" convention - Roper points the poem's reader in the direction of Walter Pater and Dante Gabriel Rossetti (2002: 224-226) - actually brings Eliot's lyric into the wider, late Victorian tradition of connecting literature and painting. Significantly, in the late Victorian era, this practice involved writing poetry on the theme of pictures, with which, as observed by Marion Thain, "fin de siècle poets sought to find this still moment in the midst of perpetual flux" which Pater both feared and celebrated in the Conclusion to The Renaissance. ${ }^{7}$ But the poets knew that the artistic attempt to transcend the temporal flux had its ethical price. This type of an artistic awareness is illustrated by Thain with Rosamund Marriott Watson's poem on Burne-Jones's The Depth of the Sea: a mermaid - an allegory of art - captures a beautiful sailor, but she is oblivious of the fact that it is his death which makes him enter her underwater realm (2007: 227).

"La Figlia" - as the poems of the nineties - weaves into a single braid three types of Decadent response to the time flow: acute anxiety caused by a sense of temporal flux, an endeavour to still it through art, and an awareness of the high price of such aestheticization. Eliot's speaker preserves the moment in the Decadent fashion, but then, he also compulsively replays it in imagination and memory by changing grammatical aspects and tenses. The poem opens with a picture of a woman depicted through a series of imperative and lyrical requests. It proceeds with a speaker turning to his audience in order to explain that the picture is imaginary: the scene is described as he "would have had" it staged. But then, the tone is abruptly changed from hypothetical musings to that of resolve; and the grammatical form is altered from the imaginary past to the expression of a present obligation ("I should"). The change of tenses is accompanied by the change of pronouns: from the distancing "he," referring to the persona participating in the scene of parting, to the intimate "I" of the artist who wants to find "some way" to account for it. At that moment - once the fact that she "turned away" has been stated in simple preterite - the references to the parting recede into the imaginary past ("should have been"), but only to re-emerge on the plane of simple present. 
With the interweaving of tenses and attitudes - including a command, request, hypothesis, resolve, confession, and conjecturing - the poem goes through the ebb and flow of stiff self-assertion and inadvertent self-revelation. It ends on the note of simple present and with a promise of a confession ("Sometimes these cogitations still amaze ..."). However, the promise is unfulfilled because the confessing "I" suddenly disappears, replaced, in the course of ellipsis, by the reference to the time of the day and night when the "I" is plagued by doubts. The poem's concluding phrase, then, reads: "Sometimes these cogitations still amaze / The troubled midnight and the noon's repose" (my italics).

With its hesitant phrases and grammar reliant on the imaginary past, "La Figlia" can be read as a stylistic extension of "The Love Song of J. Alfred Prufrock." Like "Prufrock," it mainly presents an event of the mind, extricated from an actual temporal sequence. (The preterite - which, at least, grammatically is the non-imaginary - is used very sparingly, only to say two things: that "She turned away" and that she "Compelled [his] imagination....") But, at the same time, it can be construed as answering the Paterian appeal to expand through art "that interval" which is our life. Yet, it falls short of the Paterian ideal of stilling the moment. Or, perhaps, it strives to parody it. While, in The Renaissance, Pater speaks of "passion" (1998: 153), "La Figlia" presents a feeling bordering on obsession, a fixation on a memory and thought. And even if, as suggested by Headings, the remembered crisis can be construed as "a Joycean epiphany - a recreated moment of dawning moral awareness" (1964: 251) - this epiphany seems purely aesthetic, and Decadently amoral. The picture of a painful - yet beautiful and sunlit - moment evokes an atmosphere of wistfulness. So, it creates "a mood" but is no incentive to action which, as Oscar Wilde tells us, solely "belongs to the sphere of ethics" (1999: 1139). Thus, "La Figlia" involves an unresolved Decadent impasse arising between the option of yielding to the destructive time flow and of that of resisting it through art, between ethical involvement and aestheticization.

\section{The girl, art and death}

The figure of the remembered and aestheticized la figlia is characteristically Eliotean, but it is also enmeshed in the Decadent tradition combining the tropes of death and artifice. Taciturn and self-contained, the girl seems different from the eponymous figure from "Portrait of a Lady." But she performs a similar role. La figlia belongs to the same type of essentially Eliotean poetic figures as the Lady a type described by Hugh Kenner as a "pseudo-Lazarus," a disquieting presence linked with the Lazarus from "Prufrock." She is one of the personae bringing forth "the ferment of an aroused personality" (1960: 27-28). In "Portrait," the woman's imagined death would extricate her from the world of artifice: it would liberate her from the social ritual of serving tea in a room decorated with "a bowl of lilacs" and from uttering platitudes about the music of Chopin (Eliot 1977: 18-19). Paradoxically, having died, she would move from this aestheticist limbo 
back to the land of the living - as the risen Lazarus. And, importantly, her resurgent humanity would become incriminating to the young man.

While disturbing the male persona in her modernist Lazarus-type role - and similarly to the Eliotean lady - la figlia also carries a residue of Decadent Aestheticist archetypes. Captured within an aesthetic vision, she is literally posed above the male figure - "on the highest pavement of the stair" like Dante's Beatrice (Bush 1984: 12) - extolled but also limited in her humanity within the Aestheticist convention. She is glorified and commodified at the same time, stirring the thought of natural mortality but also evoking the idea of aesthetic permanence. The cerebral speaker from "La Figlia" imparts to the girl's image the stony inanimateness of the tablet - of the stele Eliot intended to see on his trip - immobilizing even the sunlight, metaphorically captured, or tangled, in the "hair" of the posing girl. Effectively, "La Figlia" - being a poetic counterpart of the picture carved in stone - pays tribute to Parnassian tradition. Its stony immobility and the speaker's striving after perfection recall the tradition of Théophile Gautier's aesthetic effort in Enamels and Cameos (1852) and, in Britain, of Arthur O'Shaughnessy's recommendation for chiselled verse, the poet "carv[ing] the marble of pure thought" (1882: 404-405), and of Austin Dobson's rejection of "limp and shapeless style" (1895: 206).

Actually, there exists a strong thematic affinity between Eliot's fantasy of an Italian girl and Dobson's imaginary reminiscence of a young woman in the lyric "To a Greek Girl." In his poem, Dobson pictures the Greek girl as fully aestheticized: with "nymph-like head" and a shape "of unspoiled symmetry"; the speaker remembers "how sweet" it was with her "[t]o wreathe the rustic garden-god" and "to weave a basket-braid" (my italics). The verbal echoes may be purely unintentional. But the similarity in the speakers' situations goes beyond the accidental - it bespeaks of Eliot's conscious deployment of a Decadent Aestheticist convention. In Dobson's and in Eliot's poems, the speakers freeze the moment through art and preserve it against the depredations of time. Such permanence, however, is predicated on the aestheticised reduction of the girl to an object d'art. Dobson's Greek girl is framed within a vision - "A dream of Form in days of Thought" (2012: 165-166); Eliot's Italian la figlia, likewise, is framed, though doubly so, both in the mind's eye and within a camera view.

The scene in which she features, given in just a few glimpses, can be seen as a part of a metaphorical continuum suggestive of death: the flowers, the melancholy girl, and the urn. The flowers are cut and flung "to the ground." The girl is depicted in a pose which, as suggested by Smith, "should presumably be visualized as conventionally sculptured libation-bearer in a posture of sorrow" (Smith 1956: 27). The rhyming pattern of the first stanza is functional in creating the woeful mood. It alternates brusque orders and lyrical repetitions and, then, juxtaposes them with the mournful reverberation of the sonorous "urn" in "turn." We can think of the image of the "garden urn" as bringing back the formal, ornamental gardens of Italy, which Eliot must have seen on his trip. But this architectural detail also alerts the reader to the force of artifice that shaped the gardens of late 
Victorians. Accentuating the top of the stair, the urn, the inorganic, will last when the flowers she is clasping to herself have withered. In this one glimpse, the poem celebrates artifice which was a prominent feature of the gardens of Decadence. And, just as with the gardens of Decadence, the garden in "La Figlia" is a place of suffering, emotional anguish. Thus, although very discreetly, the poem recalls the Decadent tradition of the gardens and hothouses which connoted not only artifice but also cruelty and death, ${ }^{8}$ such as the hothouse where Wilde's Dorian saw the face of Sybil's brother intent on revenging his sister's suicide.

With the organic counterpointed by the garden feature carved in stone, the intimation of death subsumed by artifice (as in a stele), and the girl's figure presented as a silent silhouette, the poem fully relies on a pattern of aestheticization. However, it can be also read as an intellectual exercise in balancing the abstract and the material, the dilemma of equal importance to Eliot and to Walter Pater. Indeed, it provides Eliot with a means to consider the Paterian dilemma of the corporeal and the spiritual. The question of integrating the somatic and the psychological was for Eliot essential. As noted by Ronald Schuchard, in July-August 1911, when on his Italian trip, Eliot was engaged in the search for pictures which "reflected the relation of the physical body to spiritual turmoil" (1999: 11). This type of connection was also significant for Pater. With the dilemma of the corporeal and the spiritual in mind, we might recall that "La Figlia Che Piange" invokes Rossetti's "Blessed Damozel," the poem which Pater discussed in "Dante Gabriel Rossetti" - the essay included in his Appreciations, with which, it is safe to assume, Eliot would have been thoroughly familiar. ${ }^{9}$ Notably, in "Dante Gabriel Rossetti" Pater eulogizes the poet's ability to encompass in one picture the physical and the abstract - indeed, a capacity which the modernist Eliot, in his "Metaphysical Poets" written in 1921, renders as the "unified sensibility." Pater praises the Dantean synthesis of material and spiritual beauty and contravenes the "false contrast or antagonism" between the soul and the body as erroneously introduced by "the schoolmen whose artificial creations those abstractions really are" (1987: 212).

It would seem that Eliot's dandified speaker is of the derogatively described "schoolmen" type. He undermines the reality of the besouled corporeal beauty, which Pater commended in his aesthetic theories and whose lack he critiqued in fiction, in the failings of the characters that - like the young Paterian Spinozian, Sebastian van Storck - reviled in purely abstract thought. ${ }^{10}$ Eliot's speaker, like Decadent dandies (and also like Pater's Sebastian) tries to disentangle himself from the sensuous realm, believing he is pure intelligence. In that, he is also reminiscent of Wilde's Dorian, who temporarily succeeds in extricating himself from the carnal - having assumed the appearance of his painted portrait - and of Huysmans's Des Esseintes, ailing, maladjusted, and living on intellectual rather than on any other nourishment, his repasts being grotesquely replaced by "a peptone enema" (1987: 208). The Eliotean speaker is of the same intellectual cast as the imaginary Sebastian, Dorian, Des Esseintes - the representatives of the Apollonian male intelligence pitched against the disruptive, chtonian, female force. ${ }^{11}$ 
He imagines the parting as a brutal severing of the body and "the soul," as the separating of the body and "the mind." The notions of the soul and the mind, which in "La Figlia" are of a metaphorical nature, would return with their theoretical Modernist authority in the philosophical vocabulary of Eliot's "Tradition and the Individual Talent." The soul would be understood as close to Aristotle's "intellect" and "form," and the mind would be described by Eliot as "unaffected. [...] inert, neutral and unchanged" or (in a word borrowed from Aristotle) as "impassible" (1976: 18, 21), that is, impervious to suffering, harm and feeling, invulnerable and unaffected. ${ }^{12}$ Yet, their Paterian antecedents, as in the rendering of the physical and the abstract in the poetic depiction of the Rossettian female, should not be forgotten.

\section{The cruel aesthete and the cognitive flâneur}

In fact, "La Figlia Che Piange" relies on the images of two figlie - the libation bearer engraved in the stele (never seen) and the girl in the garden - as aesthetically superimposed. The two are forcibly yoked together, the fusion being aesthetic and cognitive. To use the term from Emmanuel Levinas's ethics, the girl is wholly thematized. She is turned into a picture in a manner that echoes a famous decadent reduction of a youth to a painting in Wilde's Dorian Gray and a whole spectrum of the episodes in which a soul is subsumed by a portrait (as in Victorian stories of the magic picture genre ${ }^{13}$ ). This fusion of the two pictures - the imaginary and the remembered - is further represented through allusions to cinematographic technique with which, as noted by Cassandra Laity, Eliot was familiar, partly through imagism. Acquainted with the techniques of cinematography, in poetry Eliot would be attentive to "abrupt optical shifts such as changes in focus and montage." In his critical prose, in turn, he would remark on "film's primacy of the "eye"" $(2004: 429,430)$ and resort to the language of cinematography while describing the objective correlative in terms of "sudden contrasts," "telescoping of images and multiplied associations" (Eliot qtd. in Laity 2004: 429). But, significantly, the Modernist avant-garde technique of the cinema allowed Eliot to cultivate the Decadent Aestheticist attitudes. With the imaginary camera operating as an instrument of a technologically advanced flâneur. He becomes a dispassionate observer of life, asserting his supremacy by visually organizing the scene.

From the flâneur's perspective, cinema and photography are the means of control. The cinematic art, as Camille Paglia has it, derives its male "Apollonian" power from the clarity of visual spacing and from the firmness of photographic frames: the "movie projector is an Apollonian straightshooter, demonstrating the link between aggression and art. Every pictorial framing is a ritual limitation [...]" (1991: 31). ${ }^{14}$ In "La Figlia Che Piange," thus, the camera allows distance. The lens separates the photographed object and the sympathetic "I." And the movie projector completes this process: the scene is framed and its moral aspect is suspended since, now, the parting is art. However, it is very important to 
note that such reading does not in any way contradict Roper's assertion that "La Figlia" is "a picture without a frame." On the contrary, it reasserts that the poem as a picture - as opposed to a painting, the image in a stele, or a camera shot does remain unframed. It comments on the Aestheticist tendency to restrict the impact of an existential experience to the effect of a conventional and controllable picture. It exposes the speaker as a dispassionate camera attempting to control the disquieting female persona through two framing powers - the visual and the intellectual - as fascinated with the scene yet unable to sympathize, and supplanting the comfort of sight for the threatening intimacy of touch.

For its intellectual voyeurism, the speaking self of "La Figlia" stands in the long row of idealized perceivers, starting, as in the account provided by Nicholls, with the figure Schopehauer describes as "the clear eye of the world" (Schopenhauer qtd. in Nicholls 1995: 48). But there is also unkindness in the Eliotean perceiver. Pitiless ("So I would have had her stand and grieve"), rendering the parting in shockingly violent imagery (as "the body torn and bruised"), he also conforms to the trope of the "cruel aesthete." Thus, he invokes the tradition of French and Italian Decadent aesthetes, comprising Huysmans's effete Des Esseintes and Gabrielle D'Annuzio's over-refined Giorgio. ${ }^{15} \mathrm{He}$ also belongs to the line of British decadent figures, comprising Wilde's Dorian Gray, horrified when Sybil starts to weep beyond the safe line of the theatrical lime-lights, and Pater's Sebastian van Storck disdainfully spurning lovely Mademoiselle Westrheene. ${ }^{16}$

$\mathrm{He}$ is a liminal figure. While embodying the features of Decadent aesthetes, the speaker from "La Figlia," at the same time, foreshadows the personae of Eliot's emblematically Modernist poems, Prufrock and Gerontion. By endlessly hypothesizing, he predates Prufrock's falsely hoping that "there will be time / . . . / for a hundred indecisions, / and for a hundred visions and revisions." His "cogitations" further reverberate in Gerontion, transformed into a sinister array of "a thousand small deliberations" which, in the phrase from the poem, promise to "[p]rotract the profit of their chilled delirium" (Eliot 1977: 13-14, 38). He "wonders," imagines, and reflects, anticipating Gerontion's five-times repeated exhortations to "Think." Admittedly, with their recurring "cogitations," "deliberations," "visions and revisions," Prufrock, Gerontion, and "La Figlia" offer a wry alternative to that type of British verse which Eliot-the-critic deprecated: the poetry filled with ideas which, in his words, "run wild and pasture on the emotions" (Eliot qtd. in Allan 1974: 76). But the alterative his early figures represent is hardly positive: obsessed with ideas that completely eschew emotion, they show us only a flip side of affection, a version of Decadent indifference, cynicism.

Decadently distanced and emotionally atrophied, the speaker from "La Figlia" is, however, ambiguous: he has no wish for ordinary intimacy, but paradoxically, he desires a total, though momentary, self-abandon - a fusion of the seer and the seen. In a moment of lyrical elation ("weave, weave the sunlight in your hair"), the Eliotean aesthete becomes a Paterian hero. His life is a flux of ephemeral impressions and streaming thoughts, a duration which Pater in his famous "Conclusion" describes as "that strange, perpetual, weaving and unweaving of ourselves" 
(1998: 152; my italics). But the moment of rapture is also a part of the flâneurian dream of transforming the spectator into the observed Other. This type of flâneurian fantasy, as Burton explains it, relies on the hope that, while "concentrating on the Other," the flâneur "may, by a transposition or interpenetration of selves, almost become the Other [...]" (1994: 5). This imaginary "interpenetration" is a corrupted version of the Schopenhauerian belief that our consolation should be found in the meditation of external objects. The ideal state, as Schopenhauer describes it, assumes the form of a "peaceful contemplation of the natural object that is directly present," to the point of being freed from "our individuality, our will." As a result, one will "continue to exist only as pure subject, the mirror of the object, so that it is as if the object existed on its own ... and we can no longer separate the intuited from the intuition as the two have become one" (2010:201; bk3:34). However, these three types of communion - the Schopenhauerian fusion achieved in the act of meditation, the flâneurian union of the seer and the seen, and the momentary romantic self-abandon in "La Figlia" - stand in the order of degradation. The moment of self-forgetting from the first stanza is immediately supplanted by neurotic self-consciousness in stanzas two and three, and peacefulness gives way to intellectual anxiety, while the originally Schopenhauerian natural or aesthetic "object" is replaced with the reminiscence of a girl reduced to an object d'art.

\section{Procedures of irony}

Reduced to a memory impress in the first lines of the poem, the girl returns with a vengeance at the poem's end, creating an ambiguity of domination and surrender characteristic of the Decadent tropes of the fearful and fascinating females. But, in the poem, this ambiguity is supplemented by other modes of ambivalence. The poem is ironic in a deeply Decadent sense. Firstly, it both affirms and effaces the speaker's subjectivity. With the distancing "he" and the intimate "I" alternating in the poem, and with the "he" teasingly suggesting both the Other (a male figure separate from the speaker) and the artistically rendered Self, the speaker's subjectivity is fluid and evanescent. Such deictic instability characterizes also other pronouns, for the poem constantly juggles with its pronominal references. The female "you," as in the imperative from the first stanza, is, in the second stanza, replaced with "her." The use of "we" (as in the lines: "I should find / . . . / some way we both should understand") leads us to think that it refers to the speaker and the girl. However, there is no reason why "we" should not indicate the speaker and the reader, signalling, in this way, that the reader is an accomplice in the act of thematizing the girl. In the latter sense, the use of "we" in "La Figlia" would anticipate Eliot's more explicit address to his reading audience when, in the lines from The Waste Land, he would turn to the reader with the words "You! hypocrite lecteur! — mon semblable,-—mon frère!" (1977: 63). Eliot also uses this subterfuge to draw us into the poem in "Portrait of a Lady," where the speak- 
ing "I" is part of "we" which, as noted by William Doreski, means alternately the "Lady and speaker" or the "speaker and reader." This ironic oscillation, as Doreski puts it, accounts for the "betrayal of the lady ... as the poem sacrifices her confidences for the greater confidence with which it addresses the reader" (1993: 9-15, 11). Finally, at the end of "La Figlia Che Piange," when the poem's tone turns into the confessional, a barrier suddenly rises between the vulnerable "I" and the remote "them": "And I wonder how they should have been together!" In this way, the speaking "I" flits from one pronoun to another, while the modes of expression range from the romantic verbal slippage ("hair over her arms, her arms full of flowers"), to self-rebuking doubt ("I should have lost a gesture and a pose"), to the assertion of cold composure.

Such a lack of stable subjectivity, as we see in "La Figlia," if viewed in the context of Paul de Man's theory of poetry, would be a feature of the lyrical mode rather than of a specific genre or an epoch. De Man repeats after Hugo Friedrich that "[w]ith Baudelaire," the master of Modernism and the prophet of Decadence, "the lyrical voice is no longer the expression of a unity between the work and the empirical person" and that poems become "texts without self, without 'I'" (qtd. in De Man 1996: 166-186, 170). To de Man, all poetic texts, not only those of modernity, are without a definite "I." This ironic rupture of continuity between the lyrical voice and the empirical self is an inherent feature of all lyrical language (1996: 183).

However, irony in "La Figlia Che Piange" not only destabilizes the speaker's subjectivity but also undermines the poem's rhetorical mode. With the speaker evading any deictic fixity, the text of "La Figlia," too, is slipping away from conceptual nets. Its tropes - which can be read, alternately, as a simile or allegory deny the reader the comfort of permanence. The parting of lovers is presented as the death of a person, likened to a desertion of the body by "the soul" and by "the mind." This severance is reflected in the poem's simile, which - being placed in the poem's middle - is also central in the literal sense:

So he would have left

As the soul leaves the body torn and bruised,

As the mind deserts the body it has used.

The simile actually divides the poem into two functional parts: (1) the verses depicting the parting scene and (2) the lines expressing the speaker's effort to understand and represent what had happened. However, Bush claims that the poem's theme should be interpreted differently - not as a split between the lovers, but as a separation of thought from feeling $(1984: 11,13)$. On the force of Bush's reading, the opening scene of parting becomes an allegory, whose significance is clarified in the poem's middle verses. Allegory, then, takes precedence over simile. These two ways of reading the poem's theme, equally legitimate - emphasising either simile or allegory - indicate the text's ironic mode of existence understood as in the definition of irony provided by de Man. Irony is in "the [con- 
tinuous] undoing of the deconstructive allegory of all tropological cognitions" (1982: 301). In "La Figlia" the simile is superseded by allegory, with the middle lines constituting what Paul de Man might call "the deconstructive moment" (the term which de Man uses in his reading of Proust's Remembrance of Things Past, to show how the apparent primacy of the metaphor is undermined by his reading of the chosen passage as a celebration of metonymy). Thus, "La Figlia" can be viewed as ironic in the deconstructive sense. It can be described as a text which, to use the words with which de Man described an excerpt from Proust, "asserts and denies the authority of its own rhetorical mode" (1980: 17).

Thus, parallel tactics are used: while the speaker from "La Figlia" exercises his fluctuating attitudes - ranging between emotional rapture and cognitive detachment - the poem-as-text, in the course of irony, diversifies its own rhetorical mode and conducts its deictic play. Such profound irony can be understood as deconstructionist. However, asserting and effacing the speaker's subjectivity, Eliot can be also seen as repeating the Byronic gesture of Romantic irony with which the poetic world and the self are recurrently destabilized and repeatedly renewed, thus, saved from the ultimate destruction. This very strategy is protective since, himself having challenged the text with irony, the poet has also sheltered it from external criticism. It is the practice of self-protection through self-critique.

Such tactics, deployed frivolously or sarcastically, were typical of Decadents. In Laforgue, for example, as put by Michelle Hanoosh, "targeting the distortions of contemporary Decadence - means targeting his own work as well, which uses Decadent forms, themes, and images to an extreme, albeit with irony; the mockery becomes blatant self-mockery" (1989: 15). The method marking Laforguian Decadence was introduced to sixteen-year-old Eliot by the works of Symons, John Davidson and Ernest Dowson. British Decadent Aestheticism - self-conscious, self-ironic, and self-parodist - had its own versions of the Laforguian strategy to offer. In Dowson's poetry, for instance, Eliot would have found a typically Laforguian anticlimax ending a passionate confession of fidelity: "I have been faithful to thee, Cynara! in my fashion" (2003: 85). In the realm of prose, in turn, he could have come across Max Beerbohm's playful evasiveness as manifest, for instance, in "Diminuendo," which Beerbohm ends with a mock-resigned "Cedo junioribus" (1896: 160) - a rather ironic counterpoint to those who knew that "the incomparable Max"17 was only twenty-four when he wrote it. Eliot would also be familiar with Oscar Wilde's paradoxical statements, which undermine the authority of each one of Wilde's theoretical claims. He was acquainted with the attitude of Wilde's ideal critic (from The Critic as Artist), who proposes to replace the effort of theoretical speculation with an equally important pleasure of a walk. Further examples of Decadent irony he could find in Beerbohm's manipulations of the sage style, as in "A Defence of Cosmetics," where Beerbohm praises artificiality with an effusion verging on the grotesque, satirising artifice and excessive make-up. However, by travestying the adopted manner of writing, that is, the style of the Victorian sages, Beerbohm also blunts the blade of his own satire. A similar type of introverted irony is manifest in Beardsley, who mocks 
his own florid literary style in Venus and Tannhäuser, as in the speech delivered by the inebriated Tala, "the tragedian," who "got no further than the first line, but repeated it again and again, with fresh accents and intonations each time, and was only silenced by the approach of the asparagus that was being served [...]" (1904: 24). The grammatical grandeur is dispelled with one trivial reference. In a manner of speaking, Tala's Eloquence chokes on "asparagus." Its spelling being identical in English and Latin, seemingly, both formal and foreign, the Beardsleian grotesque "asparagus" (as Dowson's Cynara, the name of the beloved but also, in Latin, "artichoke") dominates memory after the sentence which included it has been forgotten. It is used in Beardsley's text as it would be in the style which Paul Bourget (in the definition made available in English by Haveloc Ellis, in 1889) described as a style of decomposition: "one in which the unity of the book is decomposed to give place to the independence of the page, in which the page is decomposed to give place to the independence of the phrase, and the phrase to give place to the independence of the word" (qtd. in Dowling 1986: 133).

In a lyric about a parting, it functions as one of those Decadent nouns of which Nicholls says that they are "no longer connected to a world of objects [...] but tend to become things in themselves, opaque and immaterial" (1995: 58). They do not serve communication, but prevent contact. The word "cogitations," reified and referred to a philosophical dictionary, echoes cogito and evokes associations with the philosophy of Descartes. But in "La Figlia" the cogito of cogitations is a mere cliché, as in a daily travesty of cogito ergo sum. The deeper dimension of the Cartesian cogito - the emotional rapture - is totally missed. Actually, as indicated by Levinas, the cogito of Descartes's "Third Meditation" is no longer just a lonely reason, but is posited in a relation with Infinity (2001: 211-212). This is a cogito experiencing the state of elation which to the speaker of "La Figlia" remains unattainable. Thus, in the poem, the word which might be thought to attest the speaker's intellectual refinement, ironically, betrays his intellectual banality.

\section{Emotion}

Ultimately, the preciousness of "cogitations" also exposes his unease with emotion. In the lines preceding the Laforguian anticlimax introduced by the overformal word, the nostalgic speaker, if only for a moment of regret, drops his guard: "And I wonder how they should have been together!" Irony is there only to distract one from a twinge of pain. At this point the thematic affiliation between "La Figlia" and "Portrait of a Lady" can be illuminating once again. In "Portrait of a Lady," an echo from Matthew Arnold's "The Buried Life" is invoked to express the yearning for "the impulsive, passionate side of the human nature" or, as in the metaphor from Arnold's poem, for "the mystery of this heart which beats / So wild, so deep in us" (qtd. in Southam 1994: 60). Perhaps, then, the image of the girl leaning on the urn is part of yet another metaphorical network. While alluding to the Decadent script conflating females with death, her picture also intimates the metaphorical 
burial of the speaker's affectivity. In such a perspective, she is the mourner for the buried emotion, while the "body" of the middle lines epitomizes the affective rather than cerebral, the somatic rather than purely mental.

Genuine emotion must be "buried": covered by a mask of irony and entombed in the carapace of a studied "pose" and "gesture." However, irony is neither defence nor cure. As de Man in his Blindness and Insight explains, irony only divides the surface self: it compartmentalizes it into the empirical self and the aesthetic, or linguistic, subjectivity. The deep self - the troubling emotion and its cause - remain "buried," repressed. In de Man's words, "[t]he ironic language splits the subject into and empirical self that exists in a state of inauthenticity and a self that exists only in the form of a language that asserts the knowledge of its own inauthenticity. This does not, however, make it into an authentic language, for to know inauthenticity is not the same as to be authentic" (1996: 212). ${ }^{18}$

Indeed, in "La Figlia," though there is self-awareness - for the speaking "I" is aware of himself lacking authenticity - there is no cure. The ironic gesture is empty. While irony, in general, marks the speaker's cognitive superiority, the poem's "I" is not in the position to claim knowledge. He does not know precisely what emotion has been buried or what future might have been foreclosed ("And I wonder [...]!"). He only experiences momentary urges: excitations, shocks, wishes, whims, itches, but no "precise" emotion. There is only hazy emotionalism, or the type of affectivity which, in "Shakespeare and the Stoicism of Seneca" (1927), Eliot would term as "vague" emotion (1976: 135). In "La Figlia Che Piange," it is too early for the "precise emotion" of Eliot's later work. His poetry is not yet ready for this type of emotion which, in his criticism from the 1920's, Eliot would present as bonding in the Aristotelian sense and ordered in the Thomistic sense, or which he would see as plunging to its Dantean "depth" and ranging within the Shakespearean "width" (1976: 135, 265) ${ }^{19}$ The speaker's sensibility exhausts itself in continuous affectation - thrill, doubt, excitation, state of arous$\mathrm{al}$, festering regret.

But these are directionless impulses. Though intense, almost obsessive, his feelings are disconnected from the Other; though varied, they are crude because of the speaker's disregard of the aestheticized girl. Perhaps, the function of the poem's epigraph - Aeneas meeting the girl of unknown origin - can be construed as that of reflecting, mutatis mutandis, his unawareness of his relation with the female figure and, hence, of the provenance of his emotion. While, in Eliot's poem, no filial-maternal relationship (as in Aeneas's case) is suggested, what is at stake, is the uncertainty about the bond and of the feeling which, once suppressed, returns. Unaware of how to name his feeling, the speaker, however, is keenly conscious of his posturing. He searches for a way to part that would be "[s]imple and faithless as a smile and shake of the hand," but the very line which he utters, with its pronunciation-impeding sibilants, ironically denies his wish for ease and simplicity of the parting. His language betrays him. The awkward phrase exposes the unease, discomfort caused by an unrecognized feeling in the fragile and precious Decadent self. 
However, there is more at stake than an individual failure. As the language turns against the speaker, so the poem turns against its own Decadent strategies. It invokes them in various ways: by recreating a moment and stilling it amidst the temporal flux, in aesthetizicing the ambivalent female figure and conflating the female and death, by relying on the speaker's cognitive, coldly flâneurian, attitude and using twofold strategies of evasion - rendering subjectivity as indeterminate and destabilizing its own tropes - only to resort, finally, to the reified, pretentious word in communicating the speaker's state. Thus, while deploying the Decadent conventions, the poem also Decadently undermines the procedures through which it exists. In this sense, "La Figlia" constitutes a summation of Decadent Aesthetics and, simultaneously, functions as a critique of Decadent sensibility. With a mark of indolence in the speaker's pose and a mood of listlessness in the poem, the poem partakes in Aestheticist sensibility. Yet, it also anticipates the concerns which would stay with Eliot over the years to come - his dissatisfaction with Decadent emotionalism and preoccupation with the problem of emotion as binding and ethical. Hence, its placing at the end of the "Prufrock" volume marks a boundary in Eliot's work. The lyric on a parting with an imaginary girl is, at the same time, a poem of Eliot's parting with Decadent Aestheticism. It is his Decadent Aestheticist valediction and, perhaps, also an invitation to re-read his early work, although cautiously, through the Decadent prism.

\section{Notes}

1 For the significance of Harvard bohemianism in Eliot's reception of aestheticism, see Sigg (1989: 110-153). For Eliot's ambivalent attitude to Decadent Aestheticism, see Geary (1986). For his involvement with the British poets of the nineties and of the French Decadence, see Schuchard (1999: 8-14, 18-20).

For Oscar Wilde's impact on Eliot, see Shusterman (1990), and Budziak (2011).

Walter Pater's influence on Eliot is particularly well documented. See Smith (1949); Blissett (1953); De Laura (1965); De Laura (1966: 221); Christ (1981); Harris (1981); Conlon (1982); McGrath (1986: 43, 114-116, 139, 164-67); Loucks (1993); Bucknell (2001: 45); Lütkeimer (2001); Budziak (2008b).

The reference, as indicated by Smith (1956: 27), is to The Aeneid (i. 327). See also Bush (1984: 11).

The twofold tradition is delineated by Roper (2002: 222-223, 232nn1-2). The theme of romance is also stressed by Headings (1964: 25) and by Smith (1956: 27).

Roper directs our attention to the paintings by "Sargent, Whistler, Tissot" (2002: 223), but his emphasis is on a convention rather than on a particular painter. Indeed, the theme of the young girls holding flowers can be also found in other painters whose work Eliot might have seen: it is represented by Edward Burne-Jones's "Spring" (1869-70), and by the works of lesser painters popular at the turn of the century - the paintings by Swiss Fritz Zuber-Buhler (who exhibited also in America) and the depictions of flower girls by French Emile Vernon (who, in 1904, settled in London).

This is how Eliot paraphrased Yeats, reviewing his The Cutting of an Agate. Cited in Levenson (1986: 23).

6 The view represented by Ishak (1970: 57) and Smith (1956: 28). For the characterization of the protagonists from "Portrait of a Lady," see Smith (1956: 9-12) and Kenner (1960: 27). 
Other sources and parallels include Laforgue's "Pétition" and Rossetti's "The Blessed Damozel" (Smith 1956: 28; Headings 1964: 25). The motif of an aestheticised woman links "La Figlia" with Eliot's early piece "On a Portrait," a poem interpreted with recourse to the terminology of photographic longshots and close-ups by Paul Murphy (1996: 28). The motif can be also found in the poetry of Ezra Pound (whom Eliot read when in Harvard) represented by "Erat Hora" (published in Pound's Personae in 1909).

7 The attempt to overcome the fleeting nature of experience also motivates Pater's insistence on the physicality of language, or its "durability"; it is also behind the crafted form of the poems by Austin Dobson and Arthur O'Shaughnessy. See Budziak (2013: 183-184).

For other examples of the literary gardens of French and Belgium Decadence, including those depicted in Zola, Maeterlinck, Huysmans and Octave Mirbeau, see Nicholls (1995: 53). For British gardens of Decadence, see, for instance, Beardsley's Under the Hill (1904), chapter IX. Robert F. Fleissner indicates an echo from Appreciations in Eliot's "Prufrock" (1966: 121). Also, Eliot's critical method - the practice of gauging the value of a literary work by juxtaposing it with an extract of another - is strikingly similar to that which Pater used in Appreciations. See Budziak (2008b: 80).

10 For the relating of the concepts of the body and mind in "Sebastian van Storck," see, for instance, Budziak (2008c: 103-129).

11 The contrast as introduced and elaborated by Camille Paglia (1991: 1-39).

12 See also Budziak (2008a: 9-22, 15).

13 The genre as discussed by Kerry Powell (1983).

14 For the linking of flanerie and cinematography, see also Anke Gleber (1999: 3-22, 129-150, 151-170).

15 For figures epitomizing cruel Aestheticism, see Nicholls (1995: 53-54).

16 For the affinities between the characters of Pater's Sebastian and Wilde's Dorian, see Budziak (2008c: 120).

17 The nickname used after the title of chapter VII of Holbrook Jackson's The Eighteen Nineties: A Review of Art and Ideas at the Close of the Nineteenth Century: "The Incomparable Max."

18 De Man's observation acquires a particularly sad poignancy in the context of his personal past, which threatened to compromise his reputation and which he strived to disguise.

19 For Eliot's theory of affectivity as developing in the years 1917-1929, see, for instance, Budziak (2012).

\section{References}

Ackroyd, Peter (1984) T. S. Eliot. London: Hamish Hamilton.

Allan, Mowbray (1974) T. S. Eliot's Impersonal Theory of Poetry. Cranbury, N.J.: Associated University Presses.

Beardsley, Aubrey (1904) Under the Hill and Other Essays in Prose and Verse by Aubrey Beardsley with Illustrations. London: John Lane.

Beerbohm, Max (1896) The Works of Max Beerbohm with a Bibliography by John Lane. London: John Lane and The Bodley Head; New York: Charles Scribner's Sons.

Blissett, William (1953) "Pater and Eliot". University of Toronto Quarterly 22, 261-268.

Bucknell, Brad (2001) Literary Modernism and Musical Aesthetics. Cambridge: Cambridge University Press.

Budziak, Anna (2008a) "Between Metaphysics and Physics: Aristotelian and Postmodernist Perspectives in T. S. Eliot's Theory of Poetic Expression, the Mind and the Soul". Anglica Wratislaviensia $45,9-22$.

Budziak, Anna (2008b) "Pater and Eliot: The Case of Aestheticizing Ethics". In: Cieslak, Magdalena and Rasmus, Agnieszka (eds.) PASE Studies in Literature and Culture. Lodz: Lodz University Press, 77-85. 
Budziak, Anna (2008c) Text body and Indeterminacy: Doppelgänger Selves in Pater and Wilde. Newcastle: Cambridge Scholars.

Budziak, Anna (2011) “T. S. Eliot's Debt to Oscar Wilde: The Paradox of Impersonality". Anglica Wratislaviensia 49, 19-28.

Budziak, Anna (2012) "The idea of Emotion in T. S. Eliot and in Richard Shusterman". In: Koczanowicz Dorota and Wojciech Malecki (eds.) Shusterman's Pragmatism: Between Literature and Somaesthetics. Amsterdam: Rodopi, 33-51.

Budziak, Anna (2013) “Literature in Walter Pater's Architectural Analogy”. Brno Studies in English 39 (1), 183-198.

Burton, Richard D.E. (1994) The Flâneur and His City. Patterns of Daily life in Paris 1815-1851. Durham: University of Durham Press.

Bush, Ronald (1984) T. S. Eliot: A Study in Character and Style. Oxford, Oxford University Press.

Christ, Carol T. (1981) “T. S. Eliot and the Victorians”. Modern Philology 79 (2), 157-165.

Conlon, John (1982) 'Eliot and Pater: Criticism in Transition'. English Literature in Transition 25, 169-188.

De Laura, David (1965) "Pater and Eliot: The Origin of the Objective Correlative". Modern Language Quarterly 26, 426-431.

De Laura, David (1966) "Echoes of Butler, Browning, Conrad and Pater in the Poetry of T. S. Eliot". English Language Notes 3, 211-221.

de Man, Paul (1982) Allegories of Reading: Figural Language in Rousseau, Nietzsche, Rilke, and Proust. New Haven: Yale University Press.

de Man, Paul (1996) Blindness and Insight: Essays in the Rhetoric of Contemporary Criticism. $2^{\text {nd }}$ ed. rev. Abingdon, Routledge.

Dobson, Austin (1895) “Ars Victrix”. In: Clarence, Edmund (ed.) A Victorian Anthology, 18371895. Cambridge: Riverside Press. Bartleby.com 2003. Accessed on 10.03.2014. <www.bartleby. com/246/>.

Dobson, Austin (2012) “To a Greek Girl”. Collected Poems. Classic Reprint. 1902. London: Kegan Paul, Trench, Trübner \& Co.

Donoghue, Denis (2000) Words Alone: The Poet T. S. Eliot. New Haven, CT: Yale University Press.

Doreski, William (1993) "Politics of Discourse in Eliot's 'Portrait of a Lady"'. Yeats Eliot Review 12 (1), 9-15.

Dowling, Linda (1986) Language and Decadence in the Victorian Fin de Siècle. Princeton, Princeton University Press.

Dowson, Ernest (2003) Collected Poems. Thornton R. K. R. and Caroline Dowson (introd. and notes). Birmingham: The University of Birmingham Press.

Eliot, T. S. (1976) Selected Essays. London: Faber \& Faber.

Eliot, T. S. (1977) The Complete Poems and Plays of T. S. Eliot. London: Book Club Associates.

Fleissner, Robert F. (1966) “'Prufrock', Pater, and Richard II: Retracing a Denial of Princeship". American Literature 38, 120-123.

Freedman, Jonathan (1990) Professions of Taste: Henry James, British Aestheticism and Commodity Culture. Stanford: Stanford University Press.

Geary, E. A. (1986) "T. S. Eliot and the fin de siècle". Rocky Mountain Review of Language and Literature 40 (1/2), 21-33.

Gleber, Anke (1999) The Art of Taking a Walk. Flanerie, Literature, and Film in Weimar Culture. Princeton, N.J.: Princeton University Press.

Hanoosh, Michelle (1989) Parody and Decadence: Laforgue's Moralites Legendaires. Athens, Ohio: Ohio University Press.

Harris, Wendell V. (1981) “The Road to and from Eliot's 'Place of Pater'”. Texas Studies in Language and Literature 23, 183-196.

Headings, Philip Ray (1964) T. S. Eliot. New York: Twayne Publishers.

Huysmans J.-K. (1987) Against Nature (À Rebourse). Baldick, Robert (trans.). Harmondsworth: Penguin Books. 
Ishak, Fayek M. (1970) The Mystical Philosophy of T. S. Eliot. New Haven, CT: College and University Press.

Jackson, Holbrook (1972) The Eighteen Nineties: A Review of Art and Ideas at the Close of the Nineteenth Century. 1922. New York: Alfred A. Knopf.

Kenner, Hugh (1960) The Invisible Poet: T. S. Eliot. London: W. H. Allen.

Laity, Cassandra (2004) "T. S. Eliot and A. C. Swinburne: Decadent Bodies, Modern Visualities, and Changing Modes of Perception". Modernism / Modernity 11 (3), 425-448.

Levenson, Michael H. (1986) A Genealogy of Modernism, A Study of English Literary Doctrine 1908-1922. Cambridge: Cambridge University Press.

Levinas, Emmanuel (2001) Totality and Infinity: An Essay on Exteriority. Lingis, Alphonso (trans.) Pittsburgh, PA: Duquesen University Press.

Loucks, James F. (1993) “Pater and Carlyle in Eliot's 'Little Gidding””. Notes and Queries 238 (4), $500-502$.

Lütkeimer, Thomas (2001) Chez Soi - the Aesthetic Self in Schopenhauer, Walter Pater and T. S. Eliot. Würzburg: Königshausen \& Neumann.

McGrath, F. C. (1986) The Sensible Spirit: Walter Pater and The Modernist Paradigm. Tampa: University of South Florida Press.

Murphy, Paul (1996) "The Dream Interpretation and the Dark Continent of Femininity: 'Circe's Palace' and 'On a Portrait'”. Essays in Poetics 19 (2), 25-33.

Nicholls, Peter (1995) Modernisms: A Literary Guide. Berkeley and Los Angeles: University of California Press.

O'Shaughnessy, Arthur (1882) “Song of a Fellow Worker”. In: Fiske Bates, Charlotte (ed.) The Cambridge Book of Poetry and Song. New York: T.Y. Crowell \& Company, 404-405.

Paglia, Camille (1991) Sexual Personae: Art and Decadence from Nefertiti to Emily Dickinson. London: Penguin Books.

Pater, Walter (1987) Appreciations: With an Essay on Style. Evanston, IL: Northwestern University Press.

Pater, Walter Horatio (1998) The Renaissance: Studies in Art and Poetry. Oxford World's Classics. Oxford: Oxford University Press.

Powell, Kerry (1983) "Tom, Dick, and Dorian Gray: Magic-Picture Mania in Later Victorian Fiction". Philological Quarterly 62, 147-170.

Roper, Derek (2002) “T. S. Eliot's 'La Figlia Che Piange: A Picture without a Frame"'. Essays in Criticism 52 (3), 222-234.

Schopenhauer, Arthur (2010) The World as Will and Representation. Norman, Judith, Alistair Welchman, and Christopher Janaway (trans. and eds.). Vol. 1. Cambridge: Cambridge University Press.

Schuchard, Ronald (1999) Eliot's Dark Angel: Intersections of Life and Art. Oxford: Oxford University Press.

Scofield, Martin (1988) T. S. Eliot: The Poems. Cambridge: Cambridge University Press.

Shanahan, C. M. (1955) "Irony in Laforgue, Corbière, and Eliot". Modern Philology 53 (2), 117 128.

Shusterman, Richard (1990) "Wilde and Eliot". T. S. Eliot Annual 1, 117-144.

Shusterman, Richard (1992) Pragmatist Aesthetics: Living Beauty, Rethinking Art. Oxford, Cambridge MA: Blackwell.

Sigg, Eric (1989) The American Eliot: A Study of the Early Writings. Cambridge: Cambridge University Press.

Smith, Grover (1949) “T. S. Eliot's Lady of the Rocks". Notes and Queries 194, 123-125.

Smith, Grover (1956) T. S. Eliot's Poetry and Plays: A Study in Sources and Meaning. Chicago: Phoenix Books and The University of Chicago Press.

Southam, B. C. (1994) A Student's Guide to the Selected Poems of T. S. Eliot, $6^{\text {th }}$ ed. London: Faber \& Faber. 
Thain, Margaret (2007) "Poetry". In: Marshall, Gail (ed.) The Cambridge Companion to the Fin de Siècle. Cambridge: Cambridge University Press, 223-240.

Wilde, Oscar (1999) Collins Complete Works of Oscar Wilde: Centenary Edition. Glasgow: Harper Collins and Omnia Books.

AnNa BudZiaK teaches at the University of Wroclaw, Poland. Her research interests include British Decadent Aestheticism and Modernism. She published articles exploring the interface between literature and philosophy and has authored two book-length studies: on T. S. Eliot, and on Walter Pater and Oscar Wilde. The latter, Text, Body and Indeterminacy: Doppelgänger Selves in Pater and Wilde, was on the final shortlist for the biennial ESSE Book Award in 2010.

Address: dr hab. Anna Budziak, Phd., Institute of English Studies, University of Wroclaw, Kuznicza 22, 50-138 Wroclaw, Poland [email: budziaka@gmail.com] 
